\title{
中国版 $\mathrm{K}$ 式発達検査の標準化に関する研究 第 2 報 \\ 一中国版「得点・発達年齢換算表」の作成と \\ 1 歳〜 3歳児における検査結果の分析一
}

\author{
高 健 ${ }^{1}$ \\ Standardization of Chinese version Kyoto Development Test II: \\ The drafting of conversion table of score for developmental age and \\ analysis of the results of the tests for children aged $1-3$
}

\section{Jian $\mathrm{Gao}^{1}$}

In order to establish Chinese version of Kyoto Scale of Psychological Development Test, we administered this test for 2606 Chinese infants and children aged from six months to seven years old. According to the scores of each domain (Postural-Motor area, Cognitive-Adaptive, Language-Social area) and of all domains, we designed Chinese conversion table of score and developmental age of Chinese Version Kyoto Development Test. In relation to the analysis of the data on 1096 Chinese children aged from one to three years old, which was once printed in Page3 in Chinese Version Kyoto Development Test, we evaluated the reasonability of Chinese conversion table of score for developmental age through the study of developmental quotient (DQ) based on both Chinese Conversion Table of Score and Developmental Age and the original one.

In addition, we compared the average scores in each domain and scores in all domains. We found that in some parts of certain age groups, DQ based on the original version were significantly different between China and Japan. However, it showed no difference or a small difference in using Chinese Version Table of Score and Developmental Age. At the same time, we examined the normality of the distribution of DQ of each age group in Chinese Standardization. DQ based on the original version did not show normal distribution form in some parts of age group. On the other hand, DQ based on Chinese Version Conversion Table of Score and Developmental Age showed normal distribution form in every age group and made good progress. Consequently, we could establish the reasonability of Chinese Conversion Table of Score and Developmental Age.

Key words : Chinese Version Kyoto Development Test, Conversion Table of Score for Developmental Age, developmental quotient (DQ) 中国版 $\mathrm{K}$ 式発達検查, 得点 - 発達年齢換算表, 発達指数

\footnotetext{
1神戸学院大学

'Kobe Gakuin University
} 


\section{Iはじめに}

日本版 $\mathrm{K}$ 式発達検査（以下，原版と称す）は 生後約 100 日頃から 12.3 歳頃まで適用できる全項 目 321 項目（他に参考項目として 3 項目）から構 成されている。これらの項目は「姿勢・運動」, 「認知・適応」,「言語・社会」の3 領域に分けて 検查用紙第 1 葉〜第 5 葉に配列されている．中国 版 $\mathrm{K}$ 式発達検査（以下，中国版と称す）の標準 化には，原版方式に従って行うことを原則として いる，ところが，1人（あるいは 2 人）の検査者 が0歳から 14 歳にわたる数千名分の標準化サンプ ルのデー夕を収集すると, 長い年月がかかると思 われる.諸般の理由により, 現段階では部分的標 準化として, 中国版 $\mathrm{K}$ 式発達検査第 3 葉に重点を おくことにした.

筆者は第 1 報（高・郷間，2003）で，日本版 $\mathrm{K}$ 式検查第 3 葉を用いて, 中国 T市における 1 歳 0 カ月以上から 3 歳 6 力月の幼児 1146 名に検査を実 施した．㭘査項目の年齢別通過率及び $50 \%$ ・ $75 \%$ 通過年齢を分析することによって，日本版 $\mathrm{K}$ 式発達検査第 3 葉の中国幼児向きの適切性と難 易度を検討した. すなわち, 原版の標準化の手順 を踏み, 引き続き, その結果に基づいて, 検査項 目の取捨選択や合格基準の訂正などの変更を行う こと, 検査結果解釈のための基礎づくりとして, 「得点・発達年齢換算表」（得点から発達年齢を読 み取る）を作成することであった。

ところが，標準化しょうとする中国版 K 式発 達検査第 3 葉は, 1 歳 0 力月から 3 歳 0 カ月の幼児 に適用しているが，現実には，生活年齢が 2,3 歳であっても, 発達年齢が 7,8 月あるいは 4, 5歳のようなケースもありうるだろう。このよう な場合に備えて, 適応年齢より幅広い範囲の発達 レベルに適用できる「得点・発達年齢換算表」を 準備しておく必要があると思われる，従って，中 国版 $\mathrm{K}$ 式発達検查の「得点・発達年齡換算表」 （以下，中国版「得点・発達年齢換算表」と称す） の作成に当たっては，第 1 報（高・郷間，2003） で報告した中国版 $\mathrm{K}$ 式検査第 3 葉の標準化作業を
拡充し, 被検児の生活年齢を上限 7 歳 0 力月, 下 限 0 歳 6 力月まで広げた. 0 歳 6 カ月から 7 歳 0 カ 月にわたる 2606 人の中国被検児に対して，検查 を実施し, 得られた領域別・全領域得点に基づい て中国版「得点・発達年齢換算表」を作成した (検討 1 ).

一方，「得点・発達年踰換算表」は合理的に作 成されているかどうか，それを確かめる方法の 1 つとして, 標準化集団の各被検児の検查結果を, この換算表を用いて換算し, 得られた発達指数 （DQ）の度数分布によって確かめることである (生澤, 1998)。したがって, 本研究では第 1 報で 対象とされた 1 歳 0 力月以上から 3 歳 0 カ月の中国 被検児1096名について，原版と中国版「得点・ 発達年齢換算表」によって得られた発達指数 （DQ）を分析することにより，中国版「得点・ 発達年齢換算表」の合理性を検討した（検討 2 ）.

そこで本研究は, 中国版 $\mathrm{K}$ 式発達検査第 3 葉の 標準化の一環として, 第 1 に, 0 歳 6 力月以上か ら 7 歳 0 カ月児における検査の得点に基づいて, 中国版「得点・発達年齢換算表」の作成を試みる. 第 2 に, 1 歳 0 力月以上から 3 歳 0 力月児における 検查結果の分析を通して, 中国版「得点・発達年 齢換算表」の合理性を検討する.

\section{II 方法}

\section{1. 検討 1}

1）対象と検查方法

中国版「得点・発達年齢換算表」の作成に当た っては，中国 T市内の 7 区に重点をおき，0歳 6 カ月以上から 7 歳 0 カ月にわたる 2606 名の被検児 集団について，日本版 $\mathrm{K}$ 式発達検查を実施した. 検討 2 の被検児集団と区別をつけるように，以下， この集団を中国版「得点・発達年齢換算表」の作 成ための集団と呼ぶ.

表 1 に中国版「得点・発達年齢換算表」の作成 ための集団の年齢別，性別の人数分布を示した.

表 1 に示した年齢区分は検查用紙に示した年齢 区分と同一である，人数の内訳は家庭保育児（託 児所，保育園，幼稚園など保育施設に行っていな 
表 1 中国版「得点 - 発達年齢換算表」作成集団の年齢別・男女別人数

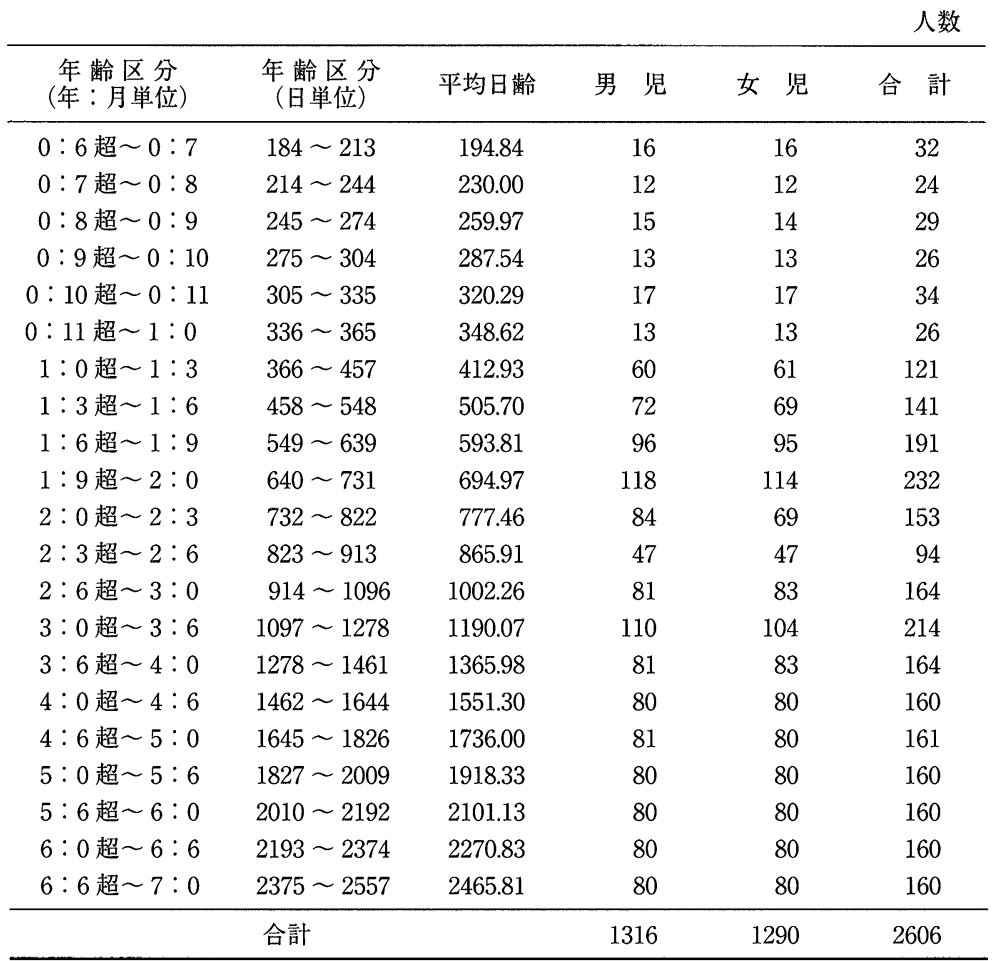

い児）が 474 名（0歳 6 力月以上〜 1歳 0 カ月児： 171 名, 1 歳 0 カ月以上 3 歳 0 カ月児：303名), その他がすべて集団保育児であった.

被検児の選出については, 住居集落の人口規模, 住居環境及び父親の職業, 保育環境を配慮して被 検児を選出した。 0 歳 6 力月以上から 1 歳 0 カ月の 被検児 171 名は，第 1 報（高・郷間，2003）での 家庭児と同地域に居住している。 3 歳 0 カ月以上 から 7 歳 0 カ月の被検児 1280 名は, 中国 $\mathrm{T}$ 市の 7 区域にある 25 カ所の幼稚園から選んだ. 1 歳 0 カ 月以上から 3 歳 0 カ月の被検児の詳細について, 第 1 報（高・郷間，2003）を参照されたい。これ らの被検児には，仮死出産・低出生体重など，明 らかな周産期異常のある児, 幼稚園生活において 行動上の問題を指摘されている児を含んでいな w.

被検児における養育環境については，2名を除
き，すべての被検児が一人っ子であった．家族形 態では核家族が70.9\%（1848/2606），三世代家族 が29.1\%（758/2606）であった.

検查の実施については，被検児の家庭や保育施 設で，一定の検査場面における個別検查として実 施されたが， 0 歳 6 力月以上から 1 歳 0 カ月児の場 合は，保護者の同伴が認められていた，検査項目 は，被検児の生活年齢と発達の状態に応じ，日本 版 $\mathrm{K}$ 式発達検査第 2 葉 第 4 葉（第 2 葉：0歳 6 力 月以上 1 歳 0 力月児の発達に適用される評価シ 一ト, 83 項目, 第 3 葉: 1 歳 0 力月以上 3 歳 0 カ 月児の発達に適用される評価シート, 54 項目, 第 4 葉： 3 歳 0 カ月以上 6 歳 6 力月児の発達に適 用される評価シート，54 項目）を用いて, 検査 を実施した（なお， 0 歳 6 力月以上から 1 歳 0 力月 児の場合は, 検査中に観察できなかった項目は保 護者からの聴き取りによる場合がある). 
実施期間は 1999年 1月～4月，2000年 12 月～ 2001 年 3 月, 2001 年 12 月〜 2002 年 2 月であった. 検查者は第 1 報（高・郷間，2003）と同一である.

2）原版の検查項目の改訂

1998年 12 月〜 1999年 2 月, 1999 年 11 月〜 2000 年 1 月, 2000 年 11 月 12 月に, $\mathrm{T}$ 市で 0 歳 6 力月 から 1 歳 0 力月児 60 名 (男児 30 人, 女児 30 人), 1 歳 0 力月から 3 歳 6 力月児 436 名（男児 232 人, 女 児 204 人), 3 歳 0 力月から 6 歳 6 力月児 347 名（男 児 187 人，女児 160 人）にプレテスト（高健ほか, 2001，1990）を行った。「言語・社会領域」の検 査結果において，通過率の低い項目，50\%。 $75 \%$ 通過年齢に顕著な日中群間差があった項目 から見て, 改訂すべき項目がいくつかあった.

(1)『 $2 \cdot 3 \cdot 4$ 数復唱』と『短文復唱 I ・ II』 は，同意味の中国語（直訳）で実施することによ って, 復唱音節が短縮され，日本の基準は中国幼 児のことばの流暢さと言語的直接記憶の能力を評 価するには，難易度が低かったことが，プレテス 卜（高健ほか, 2001，1990）から明らかになった. これに応じて, 中国版「得点・発達年齢換算表」 の作成には, 原版の『2・3・4 数復唱』の合格 基準，「3試行の内に 1 問が正しく再生されれば合 格とする（1/3）」（生澤，1998）を，「3 試行中 3 問全部に正しく再生されれば合格とする $(3 / 3) 」$ に変更した。また，原版の『短文復唱I・II』に ついて, 復唱文の意味を参考しながら, 音節の長 さも配慮し，意味を中心とされる中国語（直訳） 復唱文を，音節の長さを中心とされる中国語復唱 文に変更した。

(2)『絵の名称II』に用いている，コイン式公䍃 「電話」図版及び『硬貨の名称』, 『美の比較』は, 中国文化にそぐわなかったのに対し，代替しよう とする中国版の「電話」図版, 『紙幣の名称』, 『表情の理解』が適切であることが，プレテスト （高健ほか，2001，1990）から明らかになった。 これに応じて, 中国版「得点・発達年齢換算表」 の作成には, 原版の「電話」図版を中国版の「電 話」図版に, 『硬貨の名称 $3 / 4$ 』『紙幣の名称 3/4』に, 『美の比較 3/3』を『表情の理解 4/4』
に取り替えた。

それ以外は，原版と同じ項目を用いて，検査を 実施した.『2・3・4数復唱 $3 / 3$, 『紙幣の名称

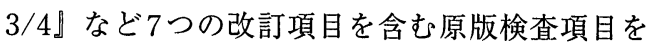
中国版検査項目とした。

3）中国版「得点・発達年齢換算表」の作成

中国版「得点・発達年齢換算表」の作成につい ては，基礎的整理として，まず，原版の項目別得 点（1歳 0 力月までは 1 項目に 1 点, 1 歳 0 カ月か ら 5 歳 0 カ月までは 5 点, 5 歳 0 カ月を超えると 10 点）（生澤，1998）を用いて，各被検児ごとに, 領域別・全領域得点を求めた。次いで, 中国版 「得点・発達年齢換算表」を作成する必要に応じ て, 生活年齢区分を 3 力月区切りになおし, 3 力 月刻みの年齢区分ごとに，生活年齢，領域別・全 領域得点のそれぞれに対して, 平均を求め, 中国 版「得点・発達年齢換算表」を作成するための, 基礎的デー夕 I・IIをまとめた（表 2-1，2-2）。基 礎的デー夕I（表 2-1）は，基礎的デー夕 II（表 22) と 1.5 カ月（45日）ずつずらしてある.

基礎的データ I ・ II の各年齢区分の平均日齢 $(\mathrm{X} 1 ， \mathrm{X} 2$ と置く）に対する平均得点（Y1，Y2 と 置く）の間に, 1次式 $[\mathrm{Y}=\mathrm{aX}+\mathrm{b}]$ によって得 点から発達年齢（DA）を推定する。ここでa (回㷌係数 regression coefficient) とb（切片 intercept）の算出のための式は, 次のようになる. $[\mathrm{a}=(\mathrm{Y} 2-\mathrm{Y} 1) /(\mathrm{X} 2-\mathrm{X} 1)]$ $[\mathrm{b}=\mathrm{Y} 2-\mathrm{aX} 2]$

$\mathrm{Y}$ (得点)によるDAXi（推定発達年令）を求 める場合は，次式になる.

$[\mathrm{DAXi}=(\mathrm{Yi}-\mathrm{b}) / \mathrm{a}]$

$$
\begin{aligned}
& Y=\text { 得点の值 } \\
& \mathrm{i}=\text { 級間の幅 }
\end{aligned}
$$

原版「得点・発達年齢換算表」の作成プロセス が公刊されていないこともあり，中国版「得点・ 発達年齢換算表」の作成には, 基本的に生澤の指 導に従い, オリジナルの年齢範囲の区切り方や計 算式を用いた。 


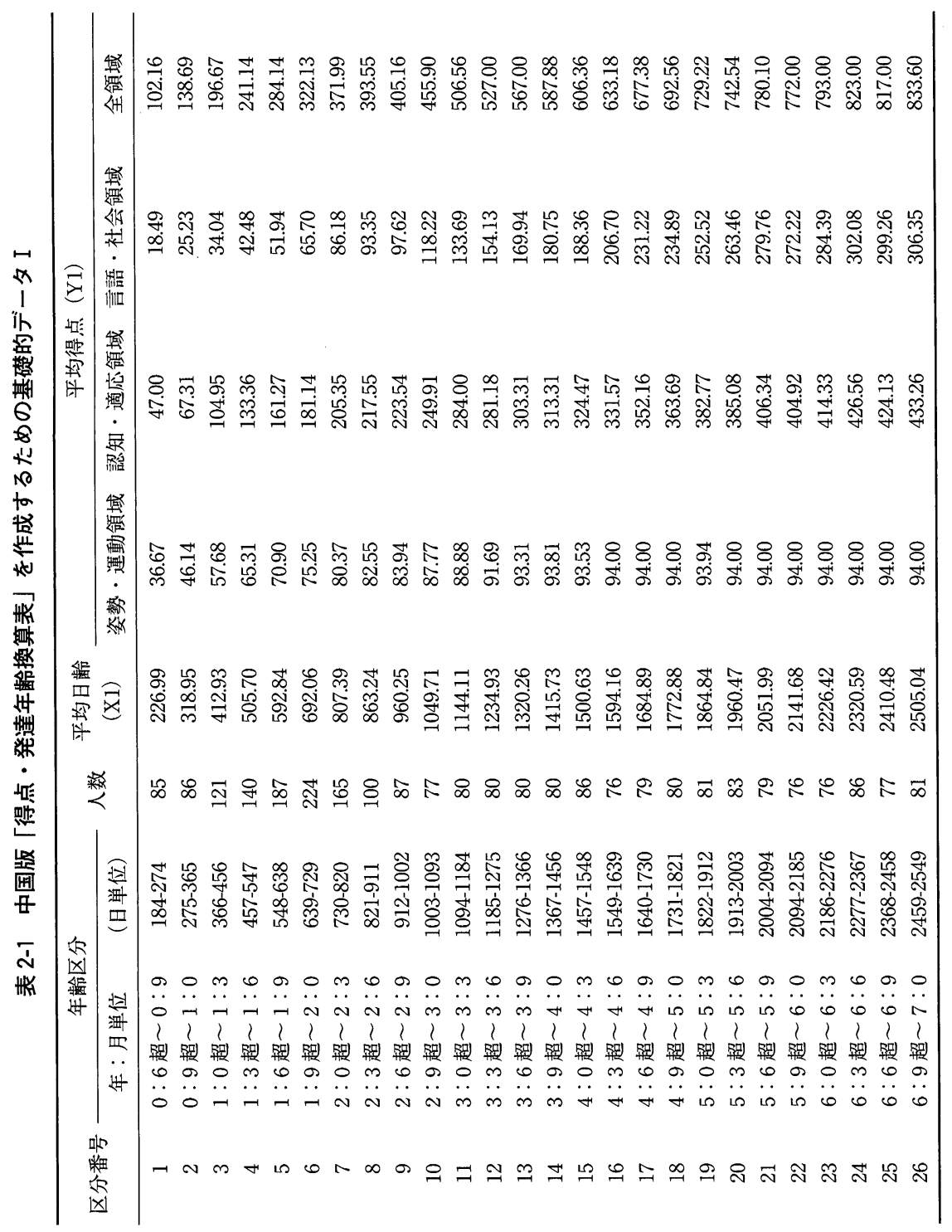




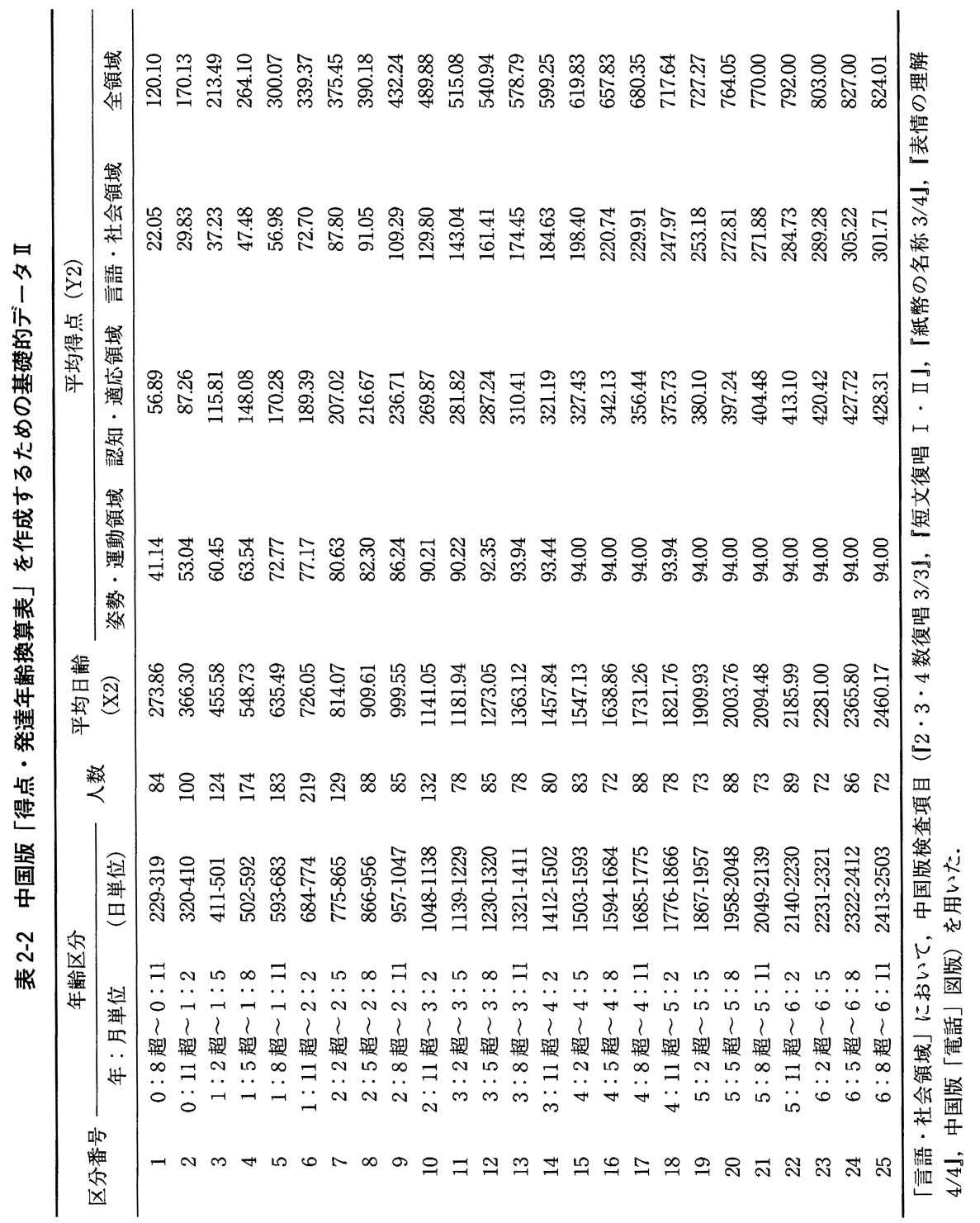




\section{2. 検討 2}

1）分析対象の検査結果の算出

中国版「得点・発達年齢換算表」の合理性の検 討に当たっては，検討 1 から， 1 歳 0 カ月以上か ら 3 歳 0 カ月の被検児 1096名の検査デー夕を取り 出し, 中国版 $K$ 式検査第 3 葉標準化集団の分析資 料とした。被検児の詳細については，第 1 報 （高・郷間，2003）を参照されたい。検査結果の 算出について, 中国版「得点・発達年齢換算表」 を用いて，領域別・全領域得点を発達年齢 （DA：得点を年齢的な発達尺度值で表したもの であり, 標準化集団の各被検児の平均得点から推 測される）に換算し，発達年齢（DA）と生活年 齢（CA）を用いて，「DQ=DA/CA × 100」（生 澤，1998）によってDQを算出した.

また，原版「得点・発達年齢換算表」を用いて， 再び DQを算出した。こうすることで，原版「得 点・発達年齢換算表」の中国幼児向けの不適合, 中国版「得点・発達年齢換算表」を作成する必要 性を検討できると思われる。

2）検查結果の分析

(1)中国版 $\mathrm{K}$ 式検查第 3 葉標準化集団（中国群） の各年齢区分における DQの平均值と標準偏差 （原版「得点・発達年齢換算表」による検查結 果: 中国 ${ }_{1}$, 中国版「得点・発達年齢換算表」に よる検査結果：中国 2 とする）を求め, 独立サン プルの $\mathrm{t}$ 検定によって，日本版 $\mathrm{K}$ 式検査第 3 葉標 準化集団（日本群）の結果（生澤，1998）と比較 した。

(2)中国版 K 式検査第 3 葉標準化集団（中国群） の各年齢区分に扔ける領域別・全領域 DQ の度数 分布を調べており，分布の歪度と尖度を求めた。

1サンプルによる Kolmogorov-Smirnov 検定を 用いて, $\mathrm{DQ}$ 平均值と標準偏差をパラメータと して正規分布と比較し, 原版及び中国版の「得 点・発達年齢換算表」によって得た DQが，正規 分布しているかどうかを検定した.

以上の分析にはSPSS 10.0J for Windowsを使 用した，有意水準は $5 \%$ （両側）とした。

\section{III 結 果}

\section{1. 作成した中国版「得点・発達年齢換算表」 の分析}

図 1 には中国版「得点・発達年齢換算表」によ る得点と発達年齢の関係を示した。その中には原 版「得点・発達年齢換算表」（生澤，1998）を用 いて作成したものも合わせて示してある．得点と 発達年齢の関係について，回帰モデルによって， 従属変数である発達年齢の変動の比 $\left(\mathrm{R}^{2}\right)$ を求め た． $\mathrm{R}^{2}$ は線型モデルへの当てはまりの良さを示 す指標であり，0と 1 の間の值をとる（山内， 1995)。領域別・全領域において, $\mathrm{R}^{2}$ 值が 0.87 0.99であり，線型モデルへの当てはまりが良く， 得点の増加に伴って発達年齢が上昇する傾向を示 したまた，原版に照らし合わせたところ， $\mathrm{R}^{2}$ 值が原版（0.90～0.99）とほぼ同じく, 線型曲線 も近似しており, 中国版への1次式の当てはめは 無理ないことを示した。

\section{1 歳〜3歳児における検査結果の分析}

1）領域別・全領域 $D Q$ の日中比較

表 3 には日中両群の各年齢区分における領域 別・全領域 DQを示した.

原版「得点・発達年齢換算表」によって得た中 国群の領域別・全領域 DQ の平均（中国 ${ }_{1}$ ）を日 本群と比較したところ, 年齢区分別にみた DQは, 「姿勢・運動領域」において，1歳6力月以上から 2 歳 6 力月の $3 つ の$ 年齢区分で,「認知・適応領域」 において，1歳 6 力月以上から 1 歳 9 力月の年齢区 分で，「言語・社会領域」において，1歳3カ月以 上から 3 歳 0 カ月の 5 つの年齢区分で,「全領域」 において，1歳 6 力月以上から 1 歳 9 力月， 2 歳 0 力月以上から 3 歳 0 力月の 3 つの年齢区分で，日 中群間に有意差が見られた。被検児の全体（1：

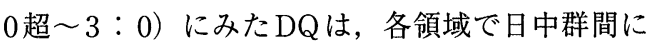
有意差が見られた。ところが, 中国版「得点・発 達年齢換算表」によって得た中国群の領域別・全 領域 $\mathrm{DQ}$ の平均（中国 ${ }_{2}$ )を日本群と比較したと ころ，上述した，日中群間で見られた有意差が， 

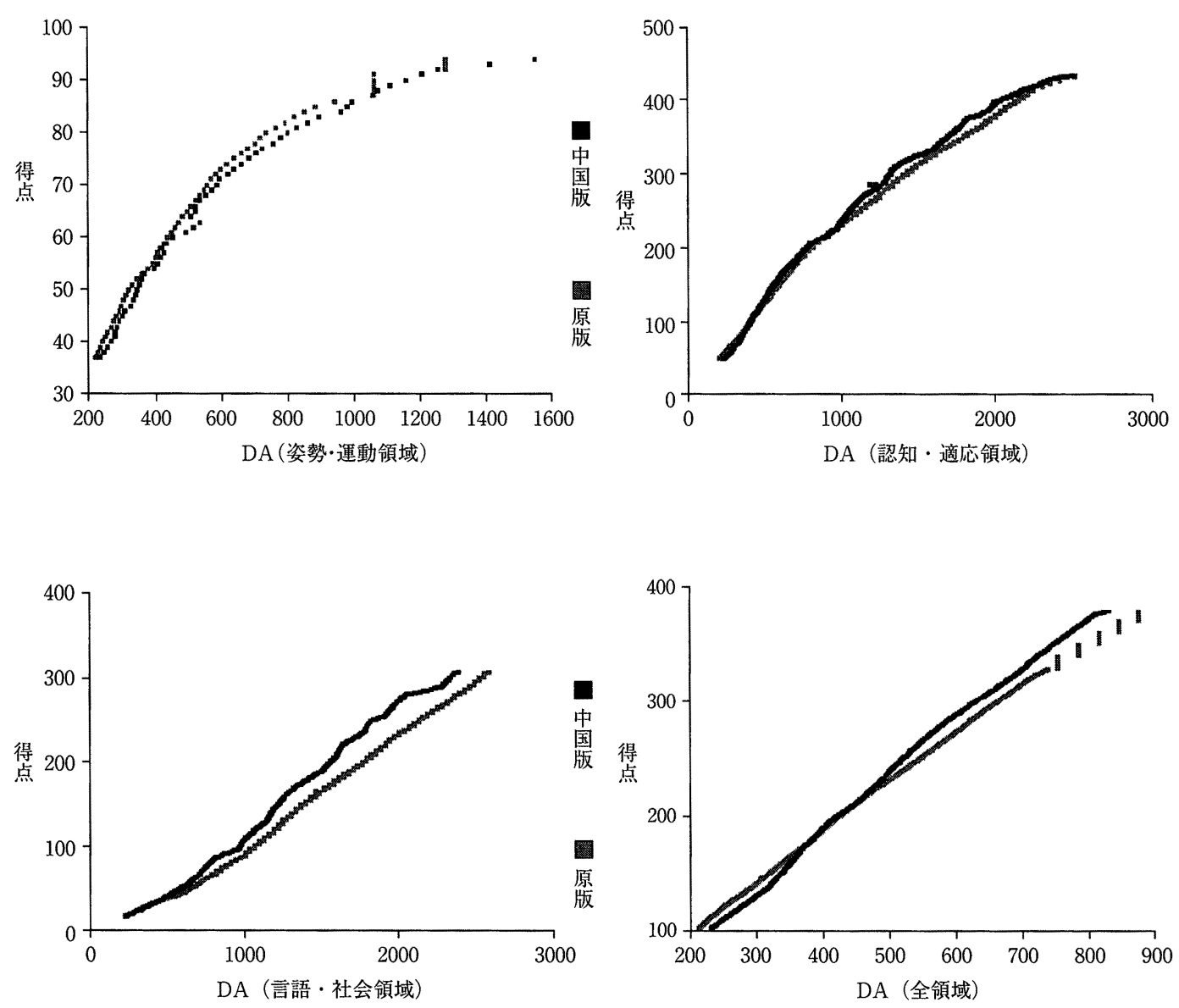

図1日中版「得点・発達年齢換算表」による得点対DA散布図

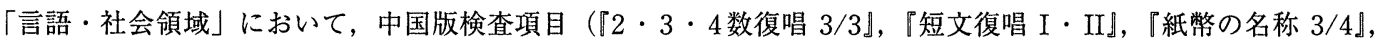
『表情の理解 4/4』，中国版「電話」図版）を用いた.

無くなったかまたは小さくなった（p<0.001 $\rightarrow$ $\mathrm{p}<0.01, \mathrm{p}<0.01 \rightarrow \mathrm{p}<0.05)$.

2）中国群の領域別・全領域 $D Q$ の分布 表 4-1，4-2，図2-1，2-2には，中国群（中国 ${ }_{1-2}$ ) の各年齢区分における，領域別・全領域 $\mathrm{DQ}$ の分 布及び，正規分布検定の結果をまとめた.

1サンプル Kolmogorov-Smirnov 検定を用い て, 各年齢区分における, 領域別・全領域 $\mathrm{DQ}$ 分 布の正規性を検定したところ，原版「得点・発達 年齢換算表」によって得た中国群（中国 1）の $\mathrm{DQ}$ 分布は, 「姿勢・運動領域」, 「認知・適応領
域」に扔いて， 1 歳 9 力月以上から 2 歳 0 力月， 2 歳 6 カ月以上から 3 歳 0 カ月の 2 つの年齢区分及び 被検児の全体，また，「認知・適応領域」の 1 歳 0 カ月以上から 1 歳 3 カ月の年齢区分で, 理論分布 との差が見られた。「言語・社会領域」「全領域」 において，被検児の全体，また，「全領域」の 1 歳 9 力月以上から 2 歳 0 力月の年齢区分で, 理論 分布との差が見られた。ところが，中国版「得 点・発達年齢換算表」によって得た中国群 $\left(\right.$ 中国 $\left.{ }_{2}\right)$ の DQ分布は，各領域において，各年齢区分でも， 被検児の全体でも，理論分布との差が見られなか 


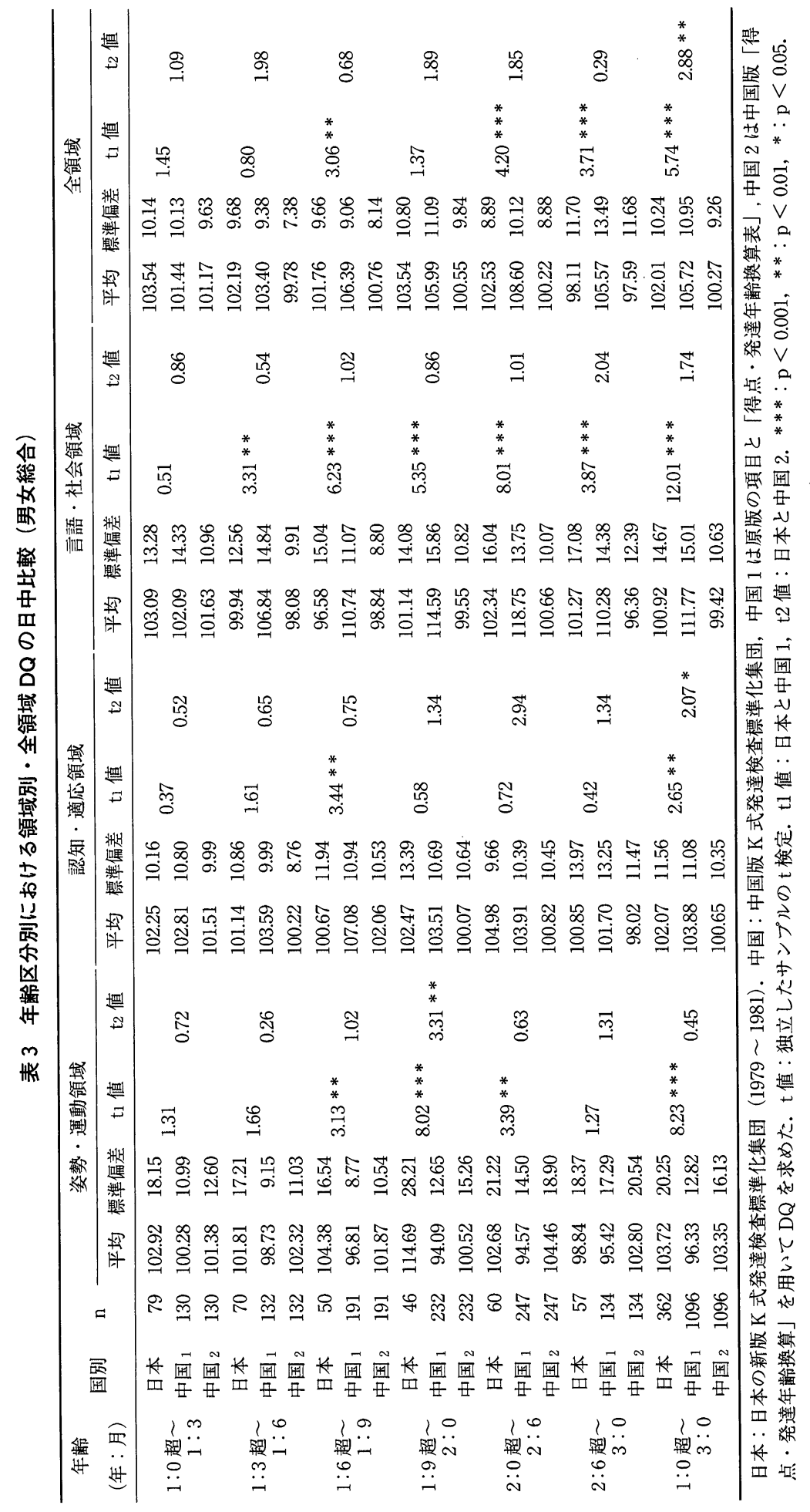




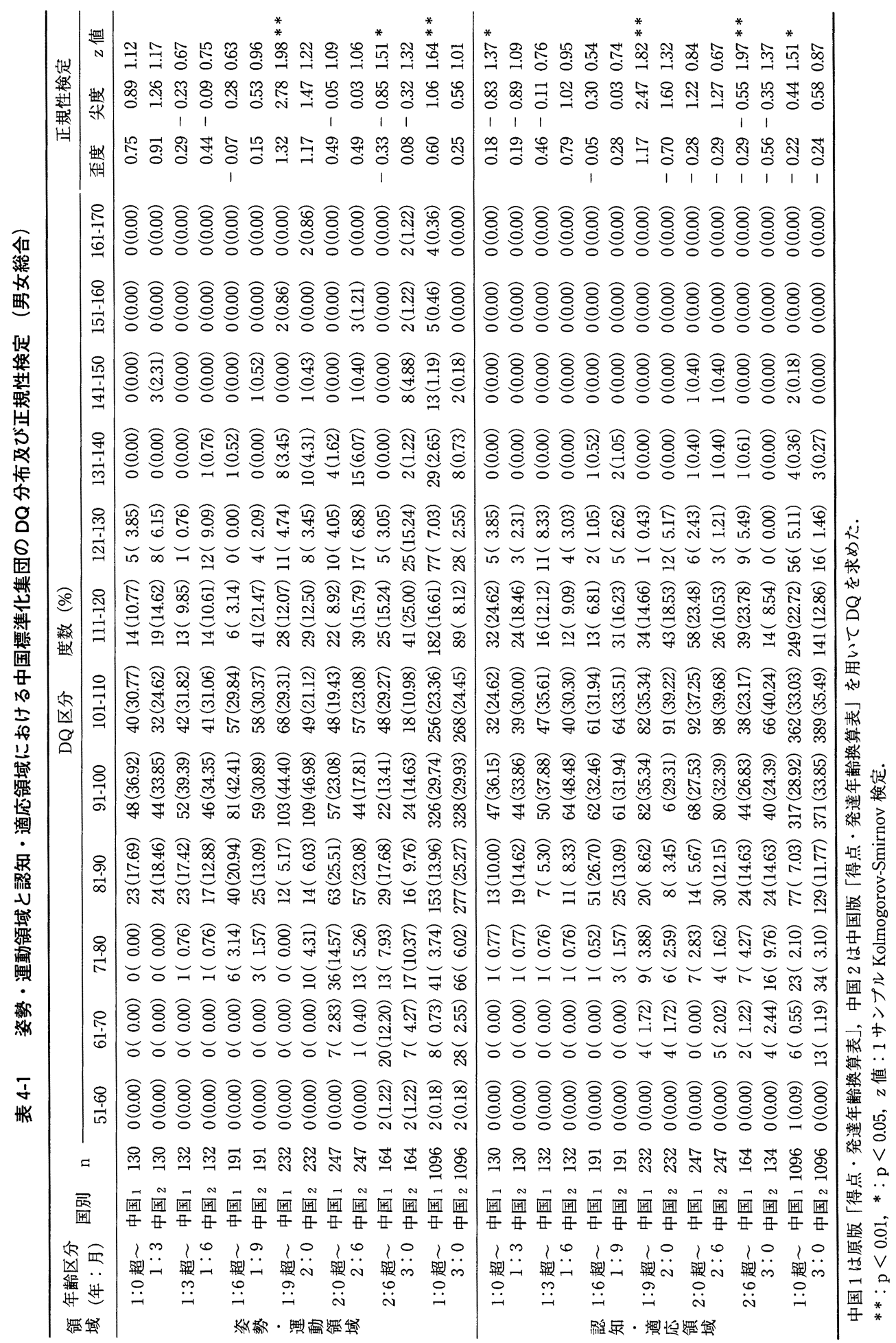




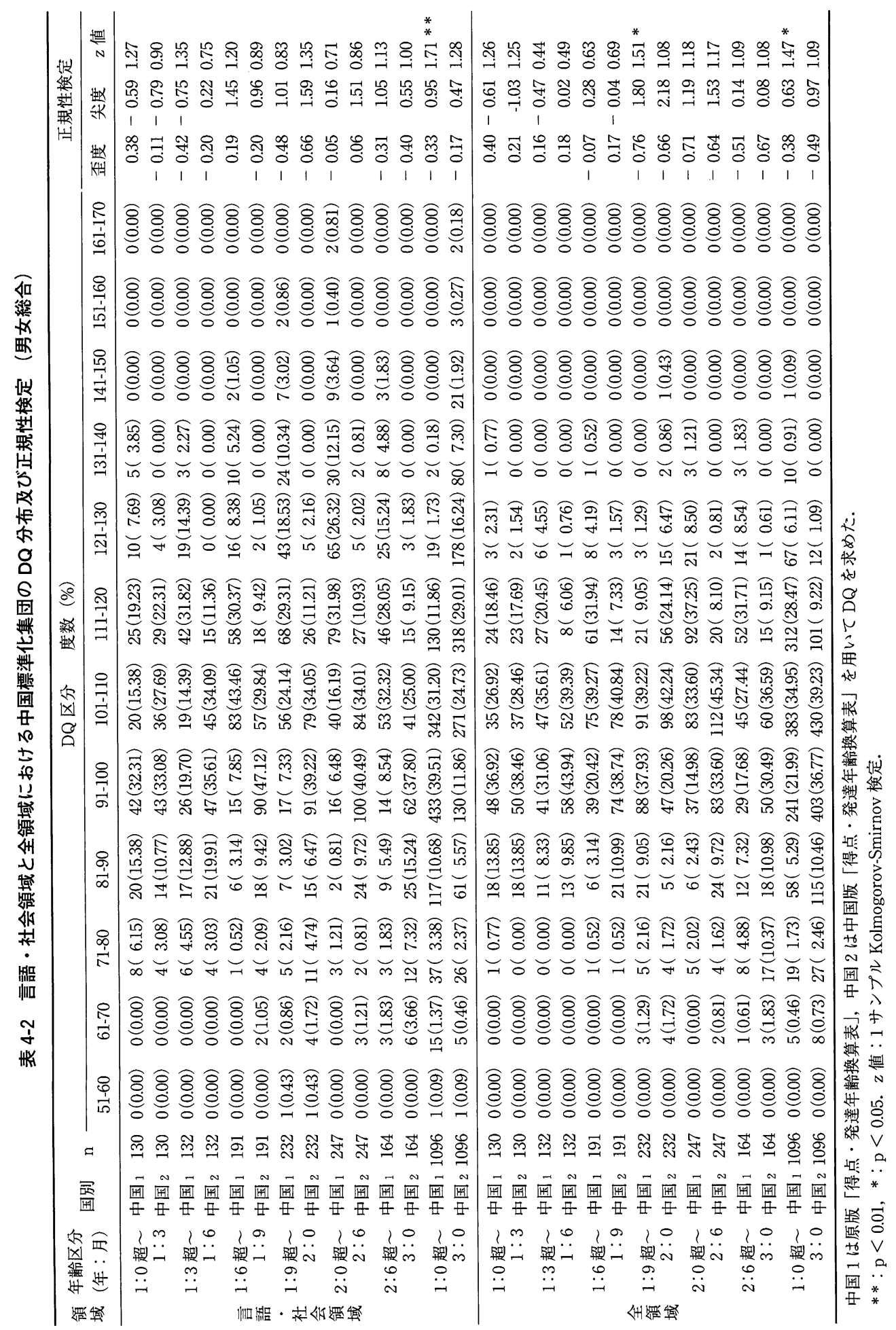




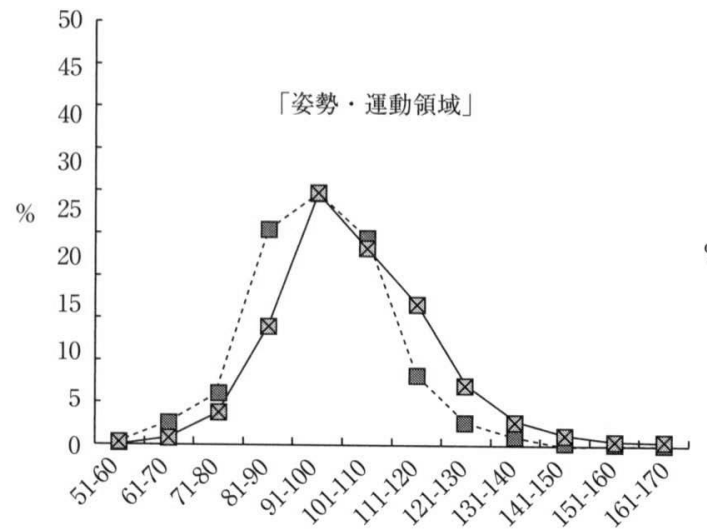

$\mathrm{DQ}$

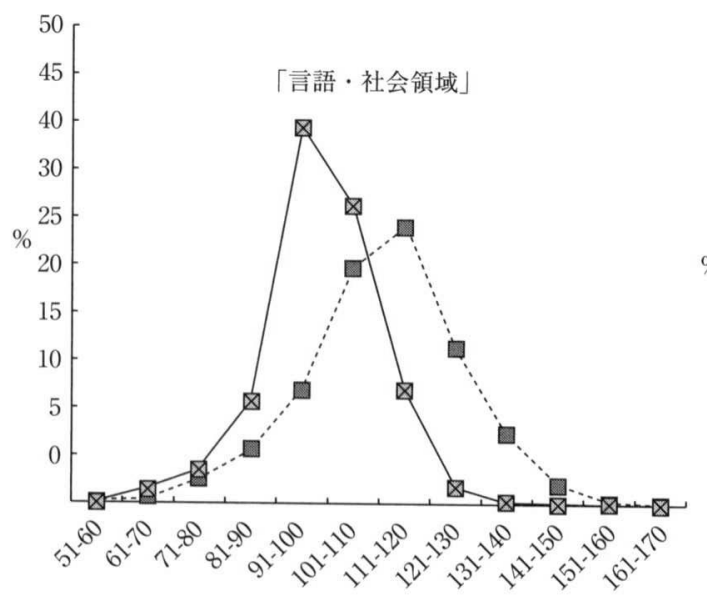

DQ

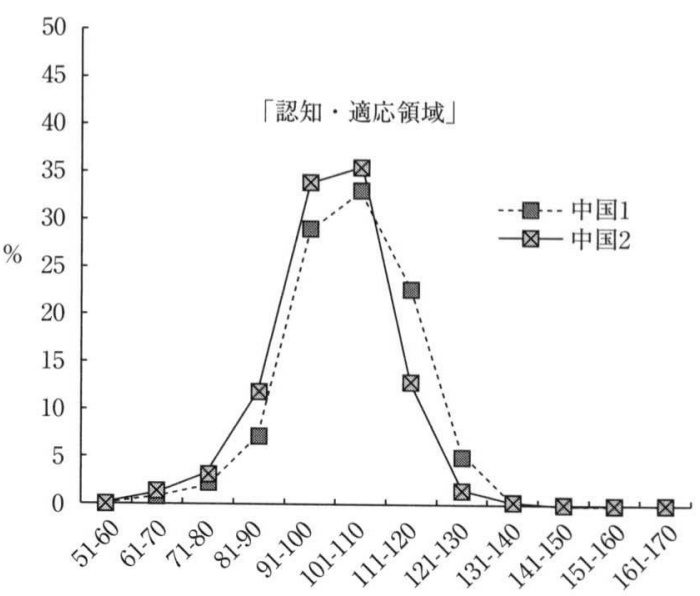

$\mathrm{DQ}$

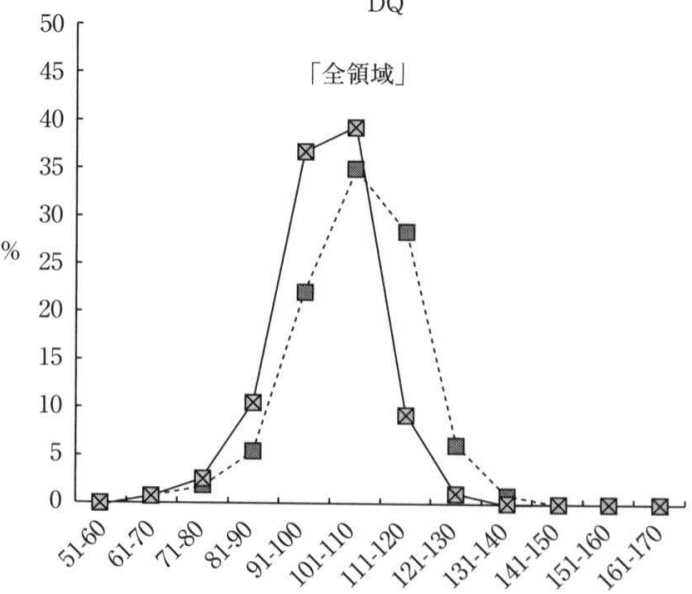

DQ

図 2-1 中国標準化集団における被検児全体のDQ分布図 $(1 ： 0$ 超 3：0)

中国 1 は原版「得点・発達年齢換算表」, 中国 2 は中国版「得点・発達年齢換算表」を用いてDQを求めた.

った．理論分布と観察データの分布との差がない （p>0.05）のは正規分布をしていると見なされ る（山内, 1995).

表4-1，4-2によって作成された図 2-1，2-2を見 れば，DQ分布の位置や形，違いを直観的に把握 することができる.

図2-1から分かるように，被検児の全体におい て, 原版「得点・発達年齢換算表」によって得た 中国群（中国）のDQ分布は，どの領域でも 100 付近を中心として, ほほ左右対称の分布になって おり, 二峰分布は見られなかったが,「姿勢・運
動」以外の領域で，分布が少し高い方に寄ってい る.ところが，中国版「得点・発達年齢換算表」 を用いることにより, 中国群の DQ分布 (中国 ${ }_{2}$ ) は, いっそう正規分布に近くなっている.

また，中国版「得点・発達年齢換算表」によっ て得た中国群 $\left(\right.$ 中国 $\left.{ }_{2}\right)$ の DQ分布の良さは, 年 歯区分別にみた $\mathrm{DQ}$ 分布から，さらに分かる、紙 面の都合で, 代表例のみを示してある（図2-2）. 各年齢区分に扔いて, 原版「得点・発達年齢換算 表」によって得た中国群（中国 ${ }_{1} ）$ の DQ分布は, すべての領域で 100 付近を中心として, ほほ左右 

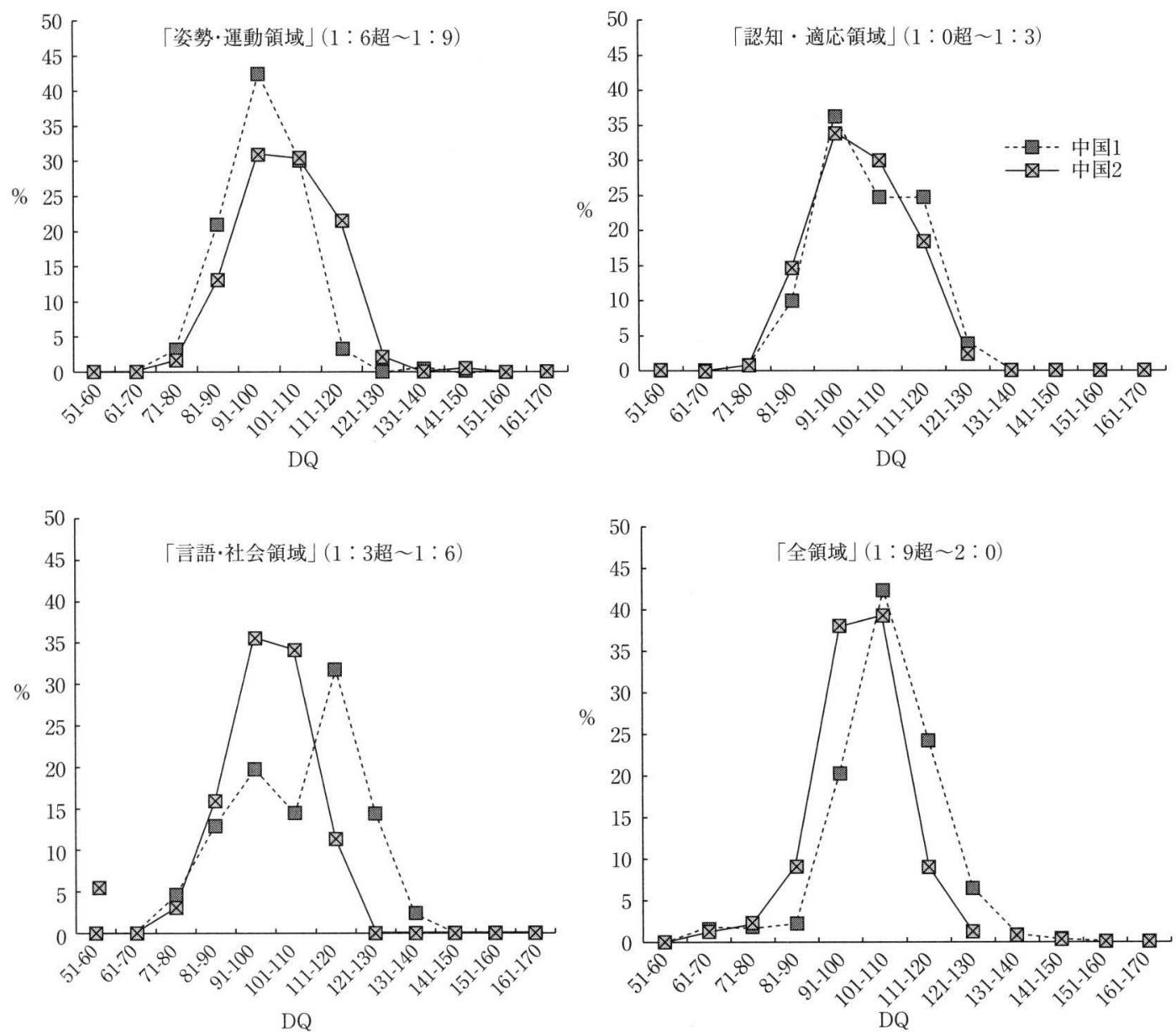

図 2-2中国標準化集団における年齢区分別 DQ分布図（年齢区分の一部）

中国 1 は原版「得点・発達年齢換算表」, 中国 2 は中国版「得点・発達年齢換算表」を用いてDQを求めた.

対称の分布になっているが，代表例のような二峰 分布または凸凹が見られた。ところが, 図2-2で 示したように，中国版「得点・発達年齢換算表」 を用いることにより，単峰または滑らかな曲線に 修正された．また，急尖（正規分布より尖ってい る）から中尖（正規分布）に，右寄りから中央寄 りに修正された例も見られた。

\section{IV 考察}

中国における従来から使われている心理検査の 多くは，外国で作成されたものを自国用に標準化
したり，これに倣って作成されたものが大部分で ある.「中国版WPPSI」の標準化の場合には (宋・朱，1987)，アメリカ方式に従って実施され た. 言語性検查のいくつかの項目にはわずかの変 更があったが，改訂は似た項目の入れ替えに止め たようである，その他，中国の子どもとアメリカ の子どもの間，難易度の違いがあった項目に，多 少の配慮を払った．更に，中国の標準化サンプル の検查結果に基づいて，アメリカ版の手続きによ り，「粗点一評価点換算表」及び「評価点合計一 IQ 換算表」を，中国の子どもの知能水準に適合 
させるように修正された，結果として，各年齢群 において, 中国版「粗点一評価点換算表」による 言語性, 動作性, 全検査の評価点合計はアメリカ の標準化サンプルの成績とほぼ同じであり, 中国 版「評価点合計一 $\mathrm{IQ}$ 換算表」による言語性, 動 作性, 全検査のIQ分布はいっそう正規分布に近 くなっていた，標準化された心理検查において， 「中国版 WPPSI」が原版の特質を失うことなく, 中国幼児にも適用できる一例として，高く評価さ れている (朱・王, 2000).

一方, 中国版に標準化された「新版 S-M 社会 生活能力検查」(張ほか, 1995) は, 日本版と同 じく, 身辺自立, 移動, 作業, 意志交換, 集団参 加, 自己統制の 6 領域にわたる 130 の生活行動項 目から構成されている。 なお, 検查結果の評価は 日本版（社会生活年齢, 社会生活指数）と違って, 粗点合計を評価点に換算し, 評価点から, 優秀〜 重度低下の9段階に評価される，検查結果の評価 が日本版と異なるので, 日中比較研究に堪えるこ とができない問題は筆者が切実に感じている（高 ほか, 1999, 2001)。

心理検查の標準化作業を概観すると，中国版 K 式発達検査の標準化には, 原版のねらい（測ろう としている能力）を変えないことと，原版の持つ 検査としての長所を失わないことが大切であると 考えられる。したがって，中国乳幼児への適用の みならず，国際的比較研究のための使用にも堪え ることを標準化の趣旨として, 本検査の場合にも, 実施法と評価法の両者の内容と様式ともに, 原版 に綿密に従った．言語性検査のいくつかの項目を 変更したが, 構造上の変更と点数の重み付けに及 んでいなかった. ありがたいことに，「得点・発 達年齢換算表」作成の統計的原理と統計的計算ま で，生澤の直接の指導を受けてきた。

作成された中国版「得点・発達年齢換算表」に は, 得点の増加に伴って発達年龄が上昇する傾向 を示しており， $\mathrm{R}^{2}$ 值が原版とほぼ同じく，線型 曲線も近似し, 統計上で満足できる結果となって いる.これは, 「得点・発達年齢換算表」を作成 する際に, 取った手続きが適切であると考えられ，
原版と同じ特徴を有する換算尺度を作成したとい えよう。なお, 統計上の適合度の良さより, 中国 版「得点・発達年齢換算表」の作成の必要性と合 理性を，実証的に検討することがさらに望まれる。

原版「得点・発達年齢換算表」によって得た $\mathrm{DQ}$ からみると, 中国版 $\mathrm{K}$ 式発達検査第 3 葉標準 化集団の領域別・全領域 $D Q$ の平均は, 日本版 $\mathrm{K}$ 式発達検查第 3 葉標準化集団と比較したところ, 有意差が認められた年齢区分は少なくなかった。 日中被検児における DQの差異は通過項目の多さ 及び得点の高さに関係し, 言語的・文化的要因に よると思われる．原版「得点・発達年齢換算表」 は日本被検児の得点に基づいて作成されたため, そのまま, 中国被検児に用いれば，中国幼児の発 達レベルを適切に評価できないと考えられる。ま た, 中国被検児の領域別・全領域 $\mathrm{DQ}$ の分布には, 正規分布が認められなかった年齢区分, $\mathrm{DQ}$ 分布 の位置や形が好ましくない年齢区分も見られた. このような $\mathrm{DQ}$ 值の不適切さから, 中国被検児の 得点のもとに中国版「得点・発達年齢換算表」を 作成する必要性が示唆された。

一方，中国版「得点・発達年齢換算表」によっ て得た DQからみると, 中国被検児の領域別・全 領域 $D Q$ の平均は, 日本版 $K$ 式発達検查第 3 葉標 準化集団と比較した結果, 原版「得点・発達年齢 換算表」を用いたことによる，日中群間に有意差 が見られた年齢区分では，中国版「得点・発達年 齢換算表」を用いたことによって，その差異が無 くなったかまたは小さくなった。このことは中国 版 $\mathrm{K}$ 式発達検查が文化的差異を超えて使用でき る可能性を有しているといえよう．また，中国被 検児の領域別・全領域 DQの分布には, 原版「得 点・発達年齢換算表」を用いたことにより，正規 分布が認められなかった年齢区分及び, DQ分布 の位置や形が好ましくない年歯区分では，中国版 「得点・発達年齢換算表」を用いたことにより， その分布が正規分布になり，位置や形も好ましい 結果であった。これらのことから，中国版「得 点・発達年齢換算表」が適切な手続きによって, 合理的作成されていることは，ある程度実証的に 
確認された.

$$
\text { V 結 論 }
$$

本研究の目的は, 中国版「得点・発達年齢換算 表」を作成し，中国版 $\mathrm{K}$ 式発達検查第 3 葉標準化

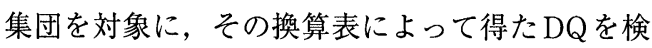
討することにより，中国版「得点・発達年齢換算 表」の合理性を確かめることにあった. その結果, 以下の点が明らかになった。

1）作成された中国版「得点・発達年齢換算表」 は，線型モデルへの当てはまりが良く, 得点の増 加に伴って発達年齢が上昇する傾向を示した。 ま た，線型モデルへの当てはまりが原版とほぼ同じ く, 線型曲線も近似している。統計上で適合度が 良い結果となっている。

2）中国版「得点・発達年齢換算表」によって 得た中国版 $\mathrm{K}$ 式発達検査第 3 葉標準化集団の領域 別・全領域 $\mathrm{DQ}$ の平均を, 日本版 $\mathrm{K}$ 式発達検查第 3 葉標準化集団と比較した結果，原版「得点・発 達年齢換算表」を用いたことにより，日中群間に 有意差が見られた年齢区分では，中国版「得点・ 発達年齢換算表」を用いたことにより，その差異 が無くなったかまたは小さくなった.

3）中国版 $K$ 式発達検査第 3 葉標準化集団の領 域別・全領域 DQ分布の正規性を検定した結果, 原版「得点・発達年齢換算表」を用いたことによ り，正規分布が認められなかった年齢区分は，中 国版「得点・発達年齢換算表」を用いたことによ り，正規分布になり，分布に改善が認められた。

本研究は主として 1 歳 0 カ月以上から 3 歳 0 力月 の健常児を対象とした中国版 $\mathrm{K}$ 式発達検査第 3 葉 の標準化を目指しているが，中国版「得点・発達 年齢換算表」は，必ずしもこの標準化集団以外の 被検児に適合しているとは言えない.したがって， 今後は，中国版 $\mathrm{K}$ 式発達検査第 3 葉標準化集団以
外の健常児や特殊児, 障害児などに，この換算表 を用いた結果を調べてみることが望まれる.

本論文の作成に関して，ご助言いただきました兵庫 教育大学障害児教育講座郷間英世教授に深謝いたしま す.

\section{文献}

生澤雅夫（1998）：新版 $\mathrm{K}$ 式発達検查法一発達検査の 考え方と使い方一, 鴆津峯眞監修, ナカニシヤ出版

高 健, 郷間英世（2003）：中国版 $\mathrm{K}$ 式発達検查の 標準化に関する研究 第 1 報一 1 歳 $~ 3$ 歳児の検査 項目の適切性と難易度の検討一，民族衛生，69(4)， $112-131$

高 健，米谷光弘，郷間英世ほか（2001）：中国新 版 $K$ 式発達検查開発のための予備的研究一 1 歳児〜 3歳児の結果を中心に一，第48回日本小児保健学会 講演集, 200-201

高健，生澤雅夫，郷間英世ほか（1999）：中国新 版 $\mathrm{K}$ 式発達検查開発のための予備的研究一 3 歳児〜 6歳児の結果を中心に一. 第46回日本小児保健学会 講演集, $228-229$

高 健，郷間英世，小沢寺敬子ほか（1999）：就学 前児の社会生活能力について一日本と中国の比較を 通しての検討一，小児保健研究，58(4)，459-464

高健, 郷間英世, 宮田広善ほか (2001)：脳性麻 痺幼児の社会生活能力に関する研究一日本と中国の 比較を通しての検討一, 発達障害研究, 22(4), 308315

宋 傑，朱 月妹（1987）：韋氏学齢前児童智力量 表（WPPSI）在全国城市的修訂，宋傑，朱月妹編， 小児智能発育検查第 2 版，245-266，上海科技出版 社

朱 臘梅, 王 小瞱 (2000)：中国心理測量近二十発 展的述評与思考，心理科学，23(2)，223-226

張 致祥, 左 啓華, 雷真武 (1995)：「嬰児一初中 学生社会生活能力量表」再標準化, 中国臨床心理学 雑誌, $3,12-15$

山内光哉（1995）：心理・教育のための統計法, サイ エンス社

(中国語文献は日本語読みで配列)

(受稿 2003. 5. 28 ; 受理 2003.11.27) 